\title{
Studies on Gene Expression in Calvaria and Serum Levels of Insulin-Like Growth Factor-I and Bone Gla Protein in the Methimazole-Induced Congenital Hypothyroid Rat
}

\author{
Hiromi TAKEUCHI, YUICHI NAKAGAWA, AND Yoshio IGARASHI \\ Department of Pediatrics, Hamamatsu University School of \\ Medicine, Hamamatsu 431-31, Japan
}

\begin{abstract}
In this study, we determined gene expression of both insulin-like growth factor (IGF)-I and bone Gla protein (BGP; osteocalcin) in calvaria in comparison with their serum levels in methimazole (MMI)-induced congenital hypothyroid (CHT) rats during the first 4 weeks of life. Pups from the MMI-treated dams revealed congenital hypothyroidism with cretinoid physical appearance and showed significant growth retardation compared to the controls. The expression of mRNA for IGF-I in the CHT pups lacked the age-associated increase with a little spurt in their somatic growth rate, although the expression in the controls increased steeply (from 1.86-fold on postnatal day 21 to 3.52 -fold on day 28 compared to the day 7 value; $P<0.01$ ) according to the spurt in their growth. Moreover, serum IGF-I levels in the CHT rats were significantly lower than those in the controls on postnatal day $28(63.0 \pm 8.0$ $\mathrm{ng} / \mathrm{m} l$ vs. $285.0 \pm 33.2 \mathrm{ng} / \mathrm{ml}$, respectively; $P<0.01$ ). Both BGP gene expression in calvaria and serum intact molecular BGP levels determined by a newly developed ELISA $(164.4 \pm 15.5 \mathrm{ng} / \mathrm{ml}$ in the CHT rat $v s .238 .6 \pm 17.8 \mathrm{ng} / \mathrm{m} l$ in the control on postnatal day $28 ; P<0.01)$ correlated well with the somatic growth in the two groups and clearly demonstrated impaired osteogenesis in the CHT rats. Further studies are needed to clarify how hypothyroidism affects somatic growth and bone metabolism; it is particularly important to understand the autocrine/paracrine mechanisms of action of IGFs in the bone matrix turnover, in vivo.
\end{abstract}

Key words: Gene expression, Calvaria, Insulin-like growth factor-I, Bone Gla protein, Congenital hypothyroidism.

(Endocrine Journal 40: 351-362, 1993)

THYROID hormone is essential for somatic growth and developmental maturation during the perinatal and postnatal periods [1-5]. Somatic growth retardation is one of the features of congenital hypothyroidism, and it is well known that low serum insulin-like growth factor (IGF)-I levels in congenital hypothyroidism [6,7] may be either a result of diminished growth hormone $(\mathrm{GH})$ secretion or due to a direct effect of hypothyroidism on IGF-I production [8]. In previous studies with the methimazole (MMI)induced hypothyroid rat treated from either the

Received: December 10, 1992

Accepted: March 19, 1993

Correspondence to: Dr. Hiromi TAKEUCHI, Department of Pediatrics, Hamamatsu University School of Medicine, 3600 Handa-cho, Hamamatsu 431-31, Japan fetal or neonatal period $[4,9,10]$, it has been reported that thyroid hormone is essential for the neonatal changes in IGF and IGF-binding protein (IGFBP) profiles and a critical period for these changes is during the perinatal development of the rat. On the one hand, in the rat hypophysectomized during the early postnatal period [11, 12], it has been demonstrated that systemically administered IGFs were poor promoters of somatic growth. Other studies also suggested that the role of IGFs as somatic growth promoters could be achieved via autocrine/paracrine mechanisms and that an increase in tissue IGF content was required for significant promotion of somatic growth [13].

Prior studies on bone metabolism in vitro have shown that IGF-I stimulates osteoblasts [14], which synthesize bone Gla protein (BGP: osteocalcin) 
during osteogenesis. BGP binds to both calcium and hydroxyapatite during mineralization of the bone tissue, and serum BGP levels have been reported as a specific marker of bone formation [15-19] and a helpful predictor of the growth response to GH therapy in humans [20-22]. But, to our knowledge, there is no report on the gene expression of either IGF-I or BGP in the bone tissue in comparison with their simultaneous serum mature protein levels in congenital hypothyroidism in vivo.

In this study, we studied these gene expression in calvaria with their serum levels in the MMIinduced congenital hypothyroid (CHT) rats during the first 4 weeks of life.

\section{Materials and Methods}

\section{Animals}

Timed pregnant Sprague-Dawley rats were obtained from Japan SLC, Inc. (Hamamatsu, Japan). Since there is no sexual dimorphism in the somatic growth of the rat within the first 30 to 35 days after birth [23], both females and males were included in the study. Litter size was adjusted to 8-10 pups and each dam was placed in a separate cage. The animals were housed in 12-h light (between 0700 and $1900 \mathrm{~h}$ ) 12-h dark animal facilities, with the ambient temperature adjusted to $22-26^{\circ} \mathrm{C}$. The dams of suckling pups and the weaning pups were allowed to drink tap water and to eat standard block feed ad libitum.

\section{Treatments}

Dams were divided into two groups, the control group and the hypothyroid group. The latter were rendered hypothyroid by administering methimazole (1-methyl-2-mercaptoimidazole: MMI; purchased from CHUGAI PHARMACEUTICAL CO., LTD., Tokyo, Japan) in the drinking water $(0.025 \%)$ from day 14 of pregnancy until the end of the study [24]. MMI readily crosses the placenta barrier in pregnant rats and is secreted into the milk in lactating dams, inducing hypothyroidism in the fetuses and maintaining it in the suckling pups [25].

\section{Growth parameters}

At 3- to 4-day intervals, body weight was measured on a digital scale (model FX-320 A and D Co., Tokyo, Japan), and tail length from the anus to the tip of the tail was measured as an index of skeletal growth [11].

\section{Biological samples}

Serum samples were collected at 1, 7, 14, 21 and 28 days of age for hormonal and/or peptide assays. In case of samples from day 1, blood from three or four animals was pooled. The animals were killed by decapitation, and blood was collected from the cervical stumps. It was then allowed to clot at $4^{\circ} \mathrm{C}$ for $15 \mathrm{~min}$, and was centrifuged at $8,000 \mathrm{~g}$ for 15 min to obtain serum. The serum samples were stored at $-80^{\circ} \mathrm{C}$ before analysis. Calvaria, collected from the same pups for serum samples except for day 1 , were quickly removed, frozen in liquid nitrogen within $10 \mathrm{~min}$ of decapitation, and subsequently stored at $-80^{\circ} \mathrm{C}$.

\section{Serum total thyroxine determination}

Serum total thyroxine $\left(T_{4}\right)$ levels were measured with a RIA kit (Ciba Corning Diagnostics Co., Ltd., Tokyo, Japan), with a detection limit of $1.0 \mu \mathrm{g} / \mathrm{d} l$.

\section{Serum IGF-I determination}

Serum IGF-I levels were measured with a RIA kit (Ciba Corning Diagnostics Co., Ltd., Tokyo, Japan), with a detection limit of $0.5 \mathrm{ng} / \mathrm{m} l$ for the human serum IGF-I concentration, and the crossreactivity with human IGF-II was $0.11 \%$ [26]. In this kit, polyclonal antibodies to human IGF-I have wide species cross-reactivity and have been successfully used in experimental studies on rats [27].

\section{Serum intact molecular BGP determination}

Serum intact molecular BGP levels were measured by a sensitive sandwich enzyme-linked immunosorbent assay (ELISA) for rat newly developed by Dr. K. Hosoda (Institute for Biomedical Research, Teijin Ltd., Tokyo, Japan) and coworkers [28]. This system is a modification of the method which was previously used for human intact molecular BGP [22, 29, 30]. 
Total cellular RNA extraction (modified AGPC method)

Total cellular RNA was isolated from the calvaria by a modified acid guanidinium thiocyanatephenol-chloroform (AGPC) method [31]. Approximately $0.5 \mathrm{~g}$ tissue was minced on ice and homogenized at room temperature (RT) with $4 \mathrm{ml}$ denaturing solution [4 M guanidine isothiocyanate (GIBCO BRL, Gaithersburg, MD, USA), $25 \mathrm{mM}$ sodium citrate, $\mathrm{pH} 7.0 ; 0.5 \%$ sarcocyl, $0.1 \mathrm{M}$ 2-mercaptoethanol] in a glass-Teflon homogenizer and subsequently transferred to a polypropylene tube. Then $0.4 \mathrm{ml}$ of $2 \mathrm{M}$ sodium acetate, $\mathrm{pH} 4.0$; $4 \mathrm{~m} l$ of phenol (saturated with $0.1 \mathrm{M}$ Tris buffer, $\mathrm{pH} 8.0$ ), and $0.8 \mathrm{~m} l$ of a chloroform-isoamyl alcohol mixture (49:1) were added to the homogenate, with thorough mixing and were shaken vigorously for $15 \mathrm{sec}$ after the addition of each reagent and cooled on ice for $20 \mathrm{~min}$. Samples were centrifuged at $8,000 \mathrm{~g}$ for $20 \mathrm{~min}$ at $4{ }^{\circ} \mathrm{C}$. After centrifugation, the aqueous phase was transferred to a fresh tube followed by precipitation with $1 \mathrm{vol}$ of isopropanol, and then placed at $-80^{\circ} \mathrm{C}$ for more than $12 \mathrm{~h}$. Sedimentation at $10,000 \mathrm{~g}$ for $20 \mathrm{~min}$ was again performed and the resulting RNA pellet was dried in vacuum at RT. The dried pellet was transferred to a $1.5 \mathrm{~m} l$ Eppendorf tube and dissolved in $0.7 \mathrm{~m} l$ protein digesting solution $[0.1 \mathrm{M}$ Tris- $\mathrm{HCl}, \mathrm{pH} 7.5 ; 0.15 \mathrm{M}$ $\mathrm{NaCl}, 10 \mathrm{mM}$ EDTA-Na, $1 \%$ sodium dodecyl sulfate (SDS), $20 \mathrm{mg} / \mathrm{ml}$ proteinase $\mathrm{K}$ (Boehringer Mannheim $\mathrm{GmbH}$, Germany)] at $37-40^{\circ} \mathrm{C}$. After dissolving, RNA was deproteinized by phenolchloroform (saturated with water) extraction followed by chloroform-isoamylalcohol extraction, and precipitated with $1 \mathrm{vol}$ of isopropanol at $-80^{\circ} \mathrm{C}$ for more than $12 \mathrm{~h}$. After centrifugation at $10,000 \mathrm{~g}$ for $20 \mathrm{~min}$ at $4^{\circ} \mathrm{C}$, the RNA pellet was rinsed with $70 \%$ ethanol, vacuum dried at RT for more than $15 \mathrm{~min}$, and dissolved in about 30-50 $\mu \mathrm{l}$ of $0.05 \% \mathrm{SDS}$ at $65^{\circ} \mathrm{C}$ for $10 \mathrm{~min}$. RNA was then quantified spectrophotometrically (model UV2200, SHIMADZU, Kyoto, Japan), and stored at $-80^{\circ} \mathrm{C}$ before analysis.

\section{Northern blot and dot blot analysis}

RNA samples were denatured with glyoxal for northern blot and dot blot analysis [32]. For northern blot analysis, denatured RNAs were electrophoresed through $1.4 \%$ agarose gel and transferred onto nylon membrane (RPN. 3050N, Amersham International plc, Amersham, Bucks, U.K.). Dot blot analysis was examined with a dot blotting apparatus (IMMUNODOT ${ }^{\circledR}$ model AE6190, ATTO Co., LTD., Tokyo, Japan). Membranes were incubated in a prehybridizing solution $(100 \mu \mathrm{g} / \mathrm{m} l$ salmon sperm DNA, $6 \times$ SSC, $10 \times$ Denhardt solution, and $1 \% \mathrm{SDS} ; 50 \mathrm{ml} /$ filter) at $42^{\circ} \mathrm{C}$ for more than $6 \mathrm{~h}$, followed by hybridization with a radioactively-labeled probe in a hybridizing solution $(100 \mu \mathrm{g} / \mathrm{m} l$ salmon sperm DNA, $6 \times \mathrm{SSC}$, $5 \%$ dextran sulfate, $50 \%$ formamide, and $1 \%$ SDS; $10 \mathrm{~m} / /$ filter) at $42^{\circ} \mathrm{C}$ on a rotating bath for more than $18 \mathrm{~h}$. The probe for rat IGF-I, coding Exon 3 region, was a 956-base-pair (bp) BamHI-EcoRI restriction fragment of a series of overlapping clones from two rat chromosomal libraries with the 3 ' end next to the T7 promoter [33]. The probe for rat BGP was a 480-bp EcoRI-restriction fragment from a rat osteosarcoma cell line (ROS 17/2) [34]. These probes were generously donated by Dr. P. Rotwein (probe for IGF-I) and Dr. J. M. Wozney (probe for BGP), respectively. Equivalent amounts of RNA/lane or dot were assessed by monitoring $\beta$-actin RNA expression hybridized with a probe purchased from the American Type Culture Collection (Rockville, Maryland, USA). The probe for IGF-I was labeled with $\left[{ }^{32} \mathrm{P}\right] \mathrm{UTP}$ (NEN Research Products/Du Pont, Boston, MA, USA; specific activity $800 \mathrm{Ci} / \mathrm{mmol}$ ) with a T7 promoter (TransProbe $\mathrm{T}$ Kit, Pharmacia LKB Biotechnology AB, Sweden) [35]. The probes for $\mathrm{BGP}$ and $\beta$-actin were labeled with $\left[{ }^{32} \mathrm{P}\right] \mathrm{dCTP}$ (NEN Research Products/Du Pont; specific activity $3,000 \mathrm{Ci} / \mathrm{mmol}$ ) with a nick translation (Nick Translation System, BRL LIFE TECHNOLOGIES, INC., MD, USA) [36]. After hybridization, membranes were rinsed twice in washing solution I $(2 \times \mathrm{SSC}$ and $0.1 \% \mathrm{SDS})$ at $42^{\circ} \mathrm{C}$ for $10 \mathrm{~min}$, followed by three washes of $20 \mathrm{~min}$ each at $42^{\circ} \mathrm{C}$ in washing solution II $(0.1 \times \mathrm{SSC}$ and $0.5 \% \times \mathrm{SDS})$. Autoradiography was performed by exposing to New-RX X-ray film (FUJI PHOTO FILM CO., LTD., Tokyo, Japan) with an intensifying screen (Sigma, St. Louis, MO, USA) at $-80^{\circ} \mathrm{C}$ overnight.

\section{Densitometry}

Autoradiographs were densitometrically scanned and the absorbance units were measured for lanes and dots. 


\section{Statistical analysis}

The significance of the differences between hypothyroid animals and controls in body weight, tail length, and serum $\mathrm{T}_{4}$, IGF-I and BGP levels was analyzed by Student's $t$-test. The densitometric data from northern and dot blots for the two groups were also analyzed by Student's $t$-test.

\section{Results}

Serum $T_{4}$ concentrations and somatic growth

Serum $T_{4}$ levels in the employed animals are shown in Fig. 1. In the MMI-treated dams and their pups (CHT in figures), these levels decreased below the detection limit throughout the study. On the other hand, control pups had the normal rat perinatal thyroid hormone serum pattern reported previously [4]. Serum $T_{4}$ levels in the control dams were within normal limits $(2-4 \mu \mathrm{g} / \mathrm{d} l)$ throughout the study, which were slightly lower than those of pups at the age of 28 days.

The somatic growth of the CHT pups was remarkably impaired both in body weight gain and in tail length gain (Fig. 2a and 2b, respectively). At the age of 28 days, both body weight and tail length were significantly lower than those in the control group $(P<0.01)$. The CHT pups had a slightly cretinoid physical appearance, already reported in the previous report [4], with blunt snouts, unfolded ears, and rounded bodies, and 3-4 day delay in eye opening, which normally occurs on postnatal day 14 .

\section{Serum IGF-I concentrations}

Serum IGF-I levels in the CHT pups $(63.0 \pm 8.0$ $\mathrm{ng} / \mathrm{ml}$, mean $\pm \mathrm{SD}$ ) were significantly lower than those in the controls $(285.0 \pm 33.2 \mathrm{ng} / \mathrm{m} l)$ on postnatal day $28(P<0.01)$. We could not determine serum IGF-I levels except on postnatal day 28 because of the limited samples available. In the present study, we could not obtain purified rat IGF-I, and a RIA kit developed for human samples was employed. Regrettably, the standards and the scales were therefore human IGF-I levels.

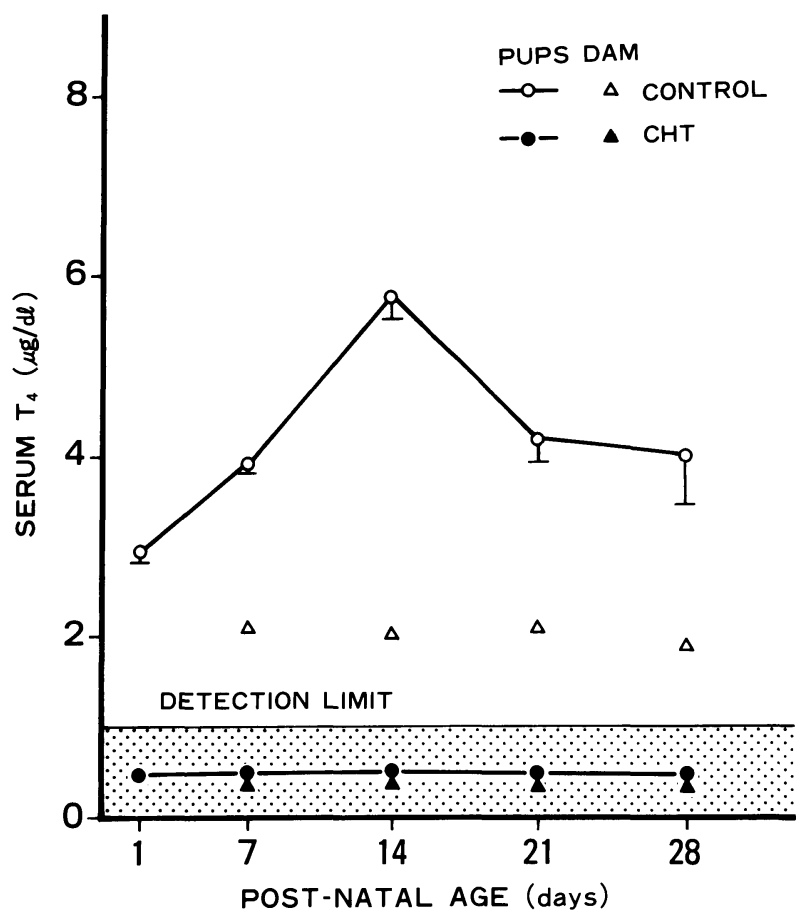

Fig. 1. Serum total $T_{4}$ levels, determined by radioimmunoassay, from serum of control (open circles) and hypothyroid (CHT; solid circles) pups as a function of postnatal age. The levels in the serum of control (open triangles) and MMI-treated (CHT; solid triangles) dams are added. Each symbol represents the mean \pm SD (day 1 samples are plural serum pools from three or four pups). Undetectable levels are shown as a dotted area.

\section{Serum intact molecular BGP concentrations}

As shown in Fig. 3, serum intact molecular BGP concentrations in the control group were increased significantly from low level of $96.0 \pm 14.3$ $\mathrm{ng} / \mathrm{ml}$ (mean and SD) on postnatal day 1 up to a level of $192.4 \pm 5.2 \mathrm{ng} / \mathrm{ml}$ on day $14(P<0.01$ us. day 1$)$ and $238.5 \pm 17.8 \mathrm{ng} / \mathrm{ml}$ on day $28(P<0.01$ vs. day 1 and day 14). On the other hand, CHT pups showed a slow rise in serum intact molecular BGP levels from $91.2 \pm 12.8 \mathrm{ng} / \mathrm{ml}$ on postnatal day 1 up to a level of $103.5 \pm 6.9 \mathrm{ng} / \mathrm{m} l$ on postnatal day 14 [not significant $(P>0.05)$ vs. day $1, P<0.01$ vs. control] and $164.4 \pm 15.5 \mathrm{ng} / \mathrm{ml}$ $(P<0.01$ vs. day 1 and vs. day $14, P<0.01$ vs. control), reaching approximately $69 \%$ of the control values on postnatal day 28 , respectively. 

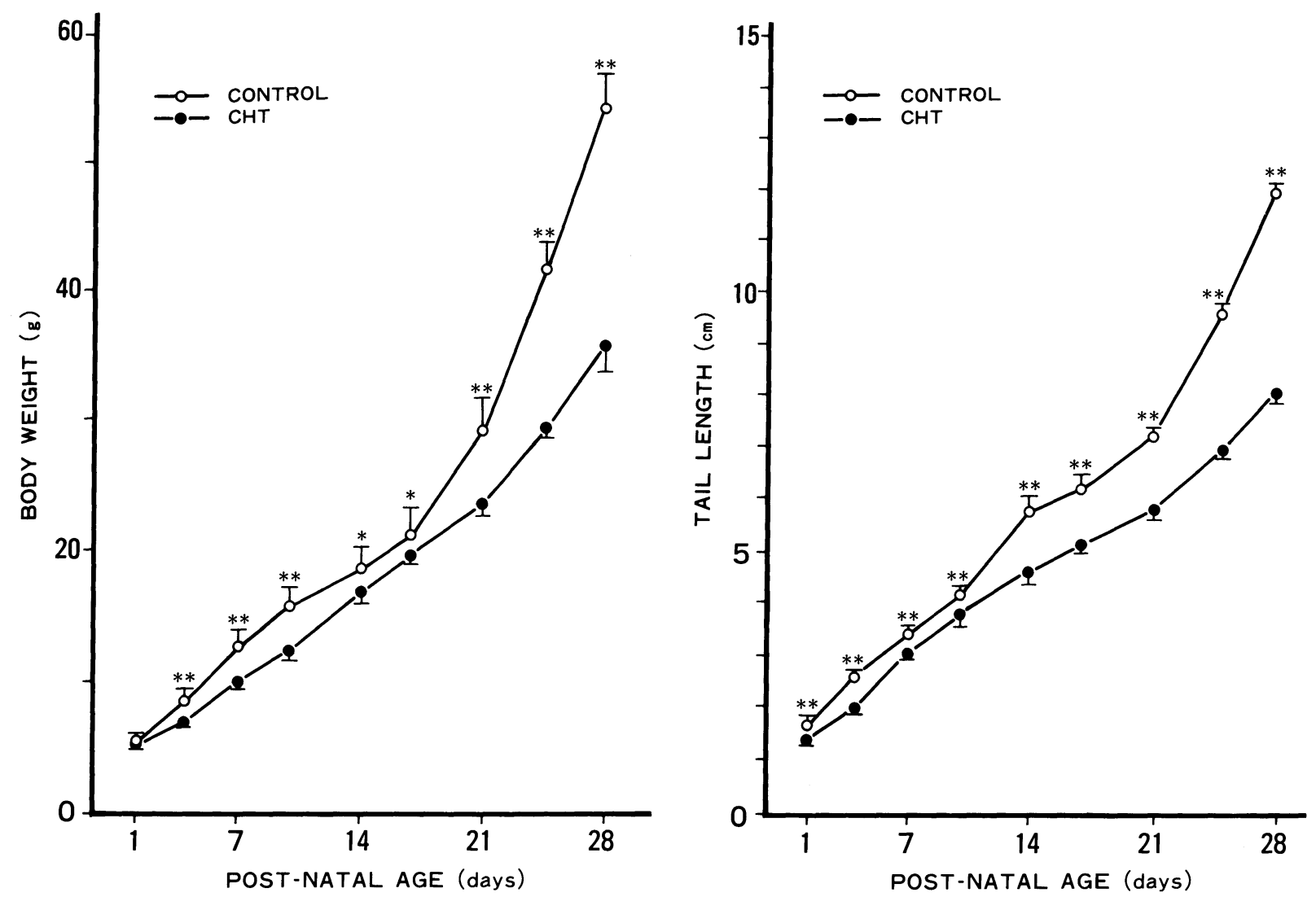

Fig. 2. Effect of MMI treatment on somatic growth. Growth patterns are shown by body weight (left panel) and tail length (right panel) of control (open circles) and hypothyroid (CHT; solid circles) rats. Each symbol represents the mean \pm SD. Statistical significance of the differences between two groups at individual time points is estimated by Student's $t$-test $(*, P<0.05$; **, $P<0.01)$.

Northern blot and dot blot analysis for IGF-I gene expression

Fig. 4 shows the result of northern blot analysis performed on pooled total cellular RNA obtained from calvaria. Two different sizes of RNA were present: $4.0-4.4$ and 1.6-2.0 kb. Although three sizes $(7.8,1.6-2.0$ and $1.0-1.4 \mathrm{~kb})$ were reported in the previous study [33], 7.8 and 1.0-1.4 kb sizes were not detected but $4.0-4.4 \mathrm{~kb}$ size was faintly present in this study. In the present study, there was no difference between the two groups in the northern blotting pattern.

To facilitate comparisons of gene expression among the sampling points in the two groups, dot blot analysis and densitometric analysis of the auto-radiographs are shown in Fig. 5a and 5b, respectively. IGF-I gene expression in the CHT rats was 2.4 times that in the control on postnatal day 7 and 1.2 times on postnatal day 28, despite low serum IGF-I levels in the CHT rats. To avoid this complexity, relative absorbancy is expressed as a function of the percentage of the value on postnatal day 7 in each group individually and the results of the densitometry are expressed as the mean $\pm \mathrm{SD}$ of five dots from the pooled RNA examined at each point. In the control rats, the expression of IGF-I increased steeply from postnatal day 21 to day 28 similar to the spurt in somatic growth shown in Fig. 2, although the expression in the CHT rats remained a small increase compared to the value for postnatal day 7 and there was no clear spurt in their somatic growth.

\section{Northern blot analysis for BGP gene expression}

In Fig. 6, the result of northern blot analysis with the rat BGP CDNA showed a single band which corresponded to a mRNA of $0.4-0.8 \mathrm{~kb}$ reported previously [34]. To clarify the difference between the two groups in gene expression and 


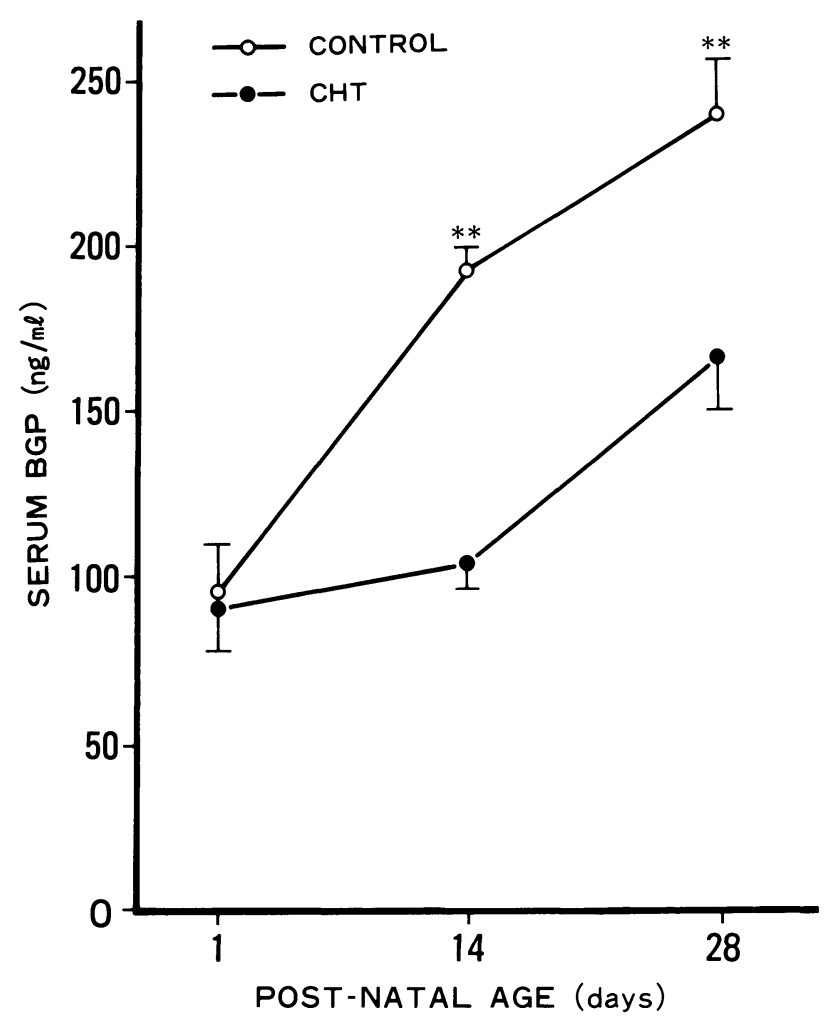

Fig. 3. Serum intact molecular BGP levels, determined by enzyme-linked immunosorbent assay, from serum of control (open circles) and hypothyroid (CHT; solid circles) rats. Each symbol represents the mean $\pm \mathrm{SD}$ (day 1 samples are plural serum pools from three or four pups). Statistical significance of the differences between two groups at individual time points are estimated by Student's $t$-test $(* *, P<0.01)$.

among the sampling points, the results of northern blot analysis performed on pooled total cellular RNA obtained from calvaria are shown (Fig. $7 \mathrm{a})$, and relative absorbancy is expressed as a function of the percentage of the value on postnatal day 7 in the control pups (Fig. 7b). BGP gene expression in the CHT rats was lower than in the controls during the experimental period from postnatal day 7 to day 28. On postnatal days 14 and 28 , the relative decrease in BGP gene expression in the calvaria of the CHT pups was very similar to that in serum intact molecular BGP levels shown in Fig. 3.

\section{Discussion}

Our results demonstrated that the expression of mRNA for IGF-I in the MMI-induced CHT rat calvaria lacked the age-associated increase with a

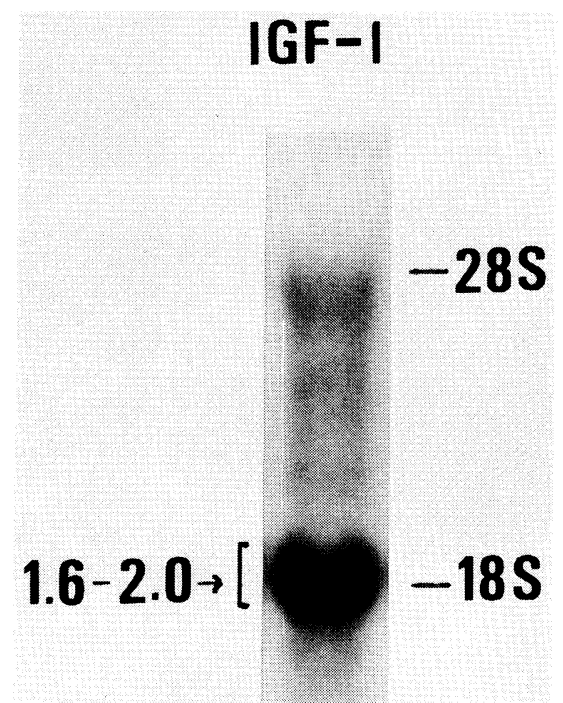

Fig. 4. Northern blot analysis of IGF-I mRNA in rat calvaria. Total cellular RNA (20 $\mu \mathrm{g}$ /lane) pooled from rat calvaria was electrophoresed, transferred to a nylon membrane and hybridized with ${ }^{32}$ P-labeled probe. The probe for IGF-I derived from rat chromosomal libraries hybridized to mRNA characteristic for rat IGF-I: 1.6-2.0 kb. Mobility of molecular size markers (28S and $18 \mathrm{~S}$ rRNA) is indicated on the right. Autoradiographic exposure was $18 \mathrm{~h}$.

little spurt in their somatic growth rate, although the expression in the control rat calvaria increased steeply accompanying the spurt in their growth from postnatal day 21 to day 28. Moreover, the serum IGF-I levels in the CHT rats were significantly lower than those in the controls on postnatal day 28. The decrease in the serum IGF-I concentration was recognized as a result of the reduced IGF-I gene expression in the liver [37].

In this study, the probe for IGF-I derived from rat chromosome libraries hybridized to only one of the mRNAs characteristic for rat IGF-I (1.6-2.0 $\mathrm{kb})$, but not to two other sizes $(7.8 \mathrm{~kb}$ and $1.0-1.4$ $\mathrm{kb}$ ) detected in the liver [33]. In the rat, it is well known that the processing of the primary IGF-I gene transcript appears to be very complicated and various alternative mRNA splicings occur at both the 5'- and 3'-ends of the gene [13]. In a previous report [37], 7.5 kb IGF-I mRNA expression in the liver with a cDNA encoding the entire coding sequence for rat IGF-I did not correlate 

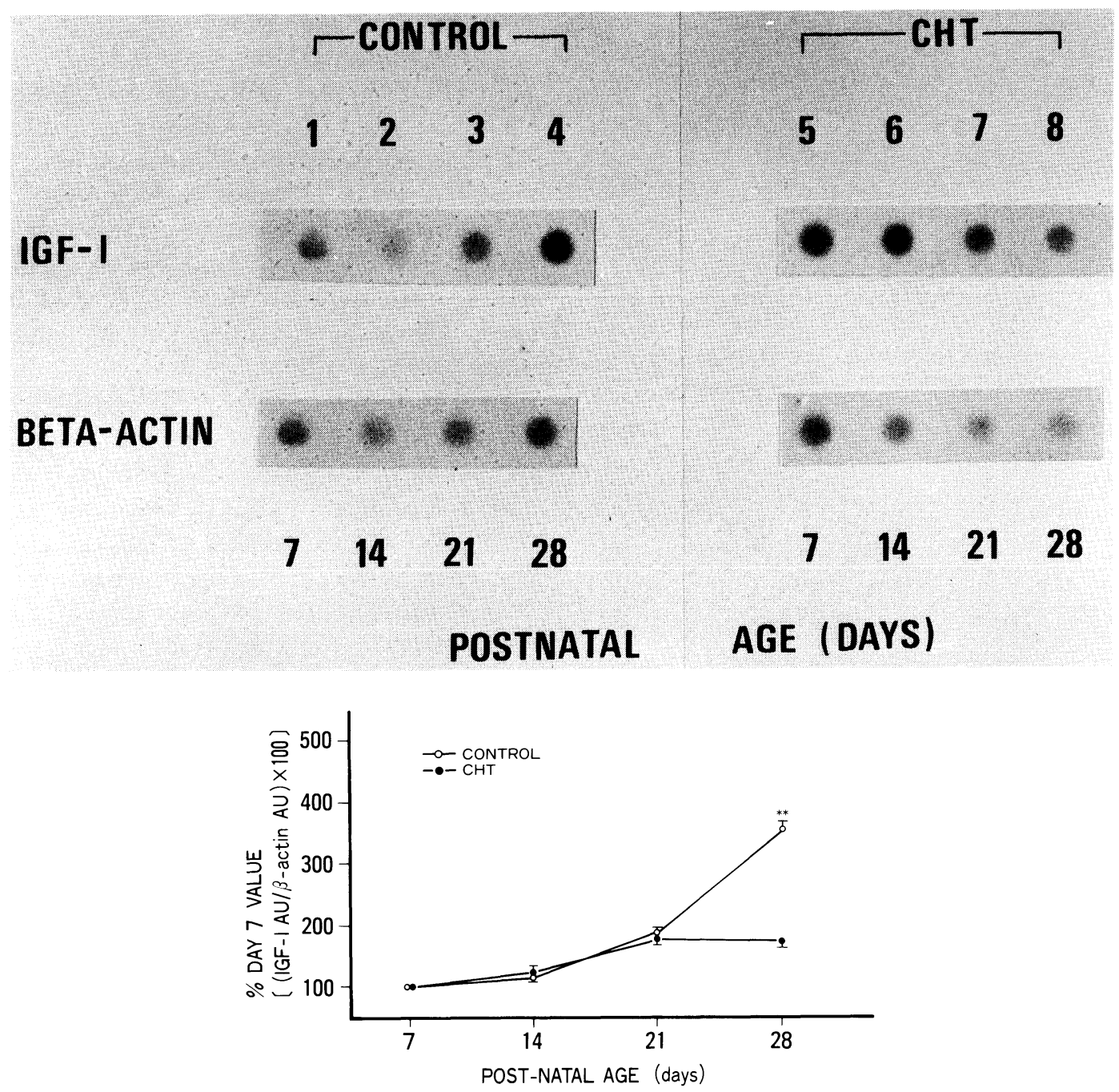

Fig. 5. Gene expression of mRNA for IGF-I in rat calvaria visualized by dot blot analysis (upper panel, a) and densitometric analysis of the autoradiographs (lower panel, b). a, Dot blot analysis of control (dots 1-4) and hypothyroid (CHT; dots 5-8) samples. Total cellular RNA (2 $\mu \mathrm{g} / \mathrm{dot})$ pooled from rat calvaria was blotted onto nylon membrane and hybridized with ${ }^{32} \mathrm{P}$-labeled probes for IGF-I and $\beta$-actin, individually. b, Densitometric analysis of the auto-radiographs, showing the mean $\pm \mathrm{SD}$ absorbance units in the control (open circles) and hypothyroid (solid circles) samples (five dots were examined at individual time points). Relative absorbancy is expressed as a function of the percentage of the value on postnatal day 7 in each group, individually. Differences between the groups were evaluated at individual time points by Student's $t$-test $(* *, P<0.01)$.

with either serum IGF-I levels or somatic growth under the dietary protein restriction, and the authors speculated that unknown mechanisms might regulate the expression of a specific IGF-I mRNA species. Besides, $1.0-1.4 \mathrm{~kb}$ and $4.0 \mathrm{~kb}$ mRNAs characteristic of rat IGF-I were not evaluated even though these sizes could be detected strongly $(1.0-1.4 \mathrm{~kb})$ or weakly $(4.0 \mathrm{~kb})$ with a rat IGF-I cDNA probe [13]. Therefore, the physiological significance of these mRNAs is unknown. Additionally, the detectable pattern of
IGF-I mRNA sizes might be different in the liver and in bone tissue, because, to our knowledge, there is no report of the detection of IGF-I mRNA in bone tissue by means of this probe. We therefore came to the conclusion that $1.6 \mathrm{~kb}$ mRNA could be evaluated as a representative IGF-I mRNA in calvaria in this study.

In previous studies, Isgaard et al. reported that the expression of mRNA for IGF-I in the growth plate of costae was diminished by hypophysectomy [38] and D'Ercole et al. demonstrated that 


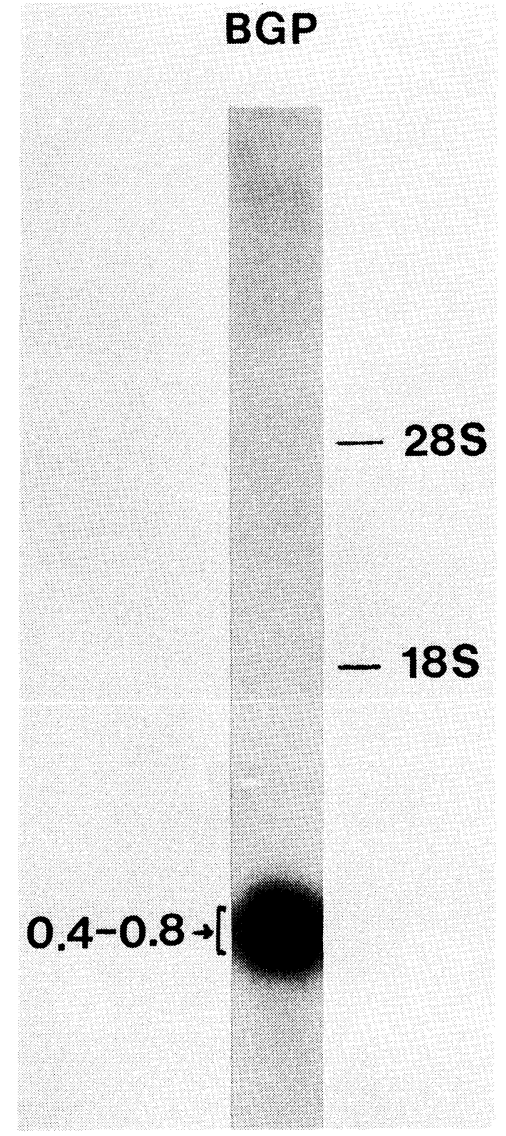

Fig. 6. Northern blot analysis of BGP mRNA in rat calvaria. Total cellular RNA (20 $\mu \mathrm{g} /$ lane $)$ pooled from rat calvaria was electrophoresed, transferred to a nylon membrane and hybridized with ${ }^{32} \mathrm{P}$-labeled probe. The probe for BGP derived from rat cDNA clone hybridized to mRNA characteristic for rat BGP: $0.4-0.8 \mathrm{~kb}$. Mobility of molecular size markers (28S and $18 \mathrm{~S}$ rRNA) is indicated on the right. Autoradiographic exposure was $18 \mathrm{~h}$.

hypophysectomy causes a decrease in the IGF-I concentration in cartilage [39]. But in our dot blot analysis, the IGF-I gene expression signal in the CHT rat was stronger than that in the control. Although we did not determine the content of mature IGF-I in the tissues, the higher gene expression of IGF-I in the CHT rat calvaria may reflect the feedback mechanism related to the decrease in locally produced IGF-I, which activates gene expression through autocrine and/or paracrine mechanisms. But further studies are needed to find the precise answer.

In the present study, impaired osteogenesis in the CHT pups was confirmed by the decrease in both BGP gene expression in the calvaria and in serum intact molecular BGP levels. BGP has been reported to be a vitamin $\mathrm{K}$-dependent bonespecific peptide produced by osteoblasts and evaluated as a marker of bone matrix turnover [40, 41]. In the rat, it has been speculated that BGP gene expression is regulated by the thyroid hormone through thyroid hormone responsive element (TRE)-like sequences in the BGP gene [42]. These TRE-like sequences are the same as those of the established TRE sites in the rat GH gene [43], and it has been reported, although in abstract form, that the expression of mRNA for BGP is regulated by the thyroid hormone status [44]. The BGP molecules, after cleavage of the propeptide, are partly released into the peripheral circulation and can be detected in serum or plasma by RIA [45-47]. But previous reports have demonstrated that the majority of their fragments, which derive from the processing during bone resorption, are also released into the circulation and that former RIAs for BGP cross-react with the fragments [48-50]. Consequently, osteoblastic bone formation could be evaluated by using a specific assay system to detect intact molecular BGP. In the present study, we employed a cloned cDNA which encodes rat BGP and a newly developed ELISA specific to rat intact molecular BGP and determined the osteogenesis in the CHT rat calvaria in vivo. Our northern blot analysis showed that the expression of mRNA for BGP in the CHT rat calvaria was lower than that in the control throughout the experimental period, from postnatal day 7 to day 28 . The serum intact molecular BGP levels in the CHT pups were also significantly lower than those in the controls on postnatal day 14 and day 28, although there was little difference between the two groups on postnatal day 1 . Besides, as shown in Fig. 2, the difference between the two groups in somatic growth became obvious from postnatal day 14 . To be brief, BGP gene expression and serum intact molecular BGP levels were well correlated with somatic growth in the two groups and confirmed the diminished osteogenesis in the CHT rat.

During this study, maternal thyroid function was also completely suppressed. As for body weight, food consumption, water intake and 


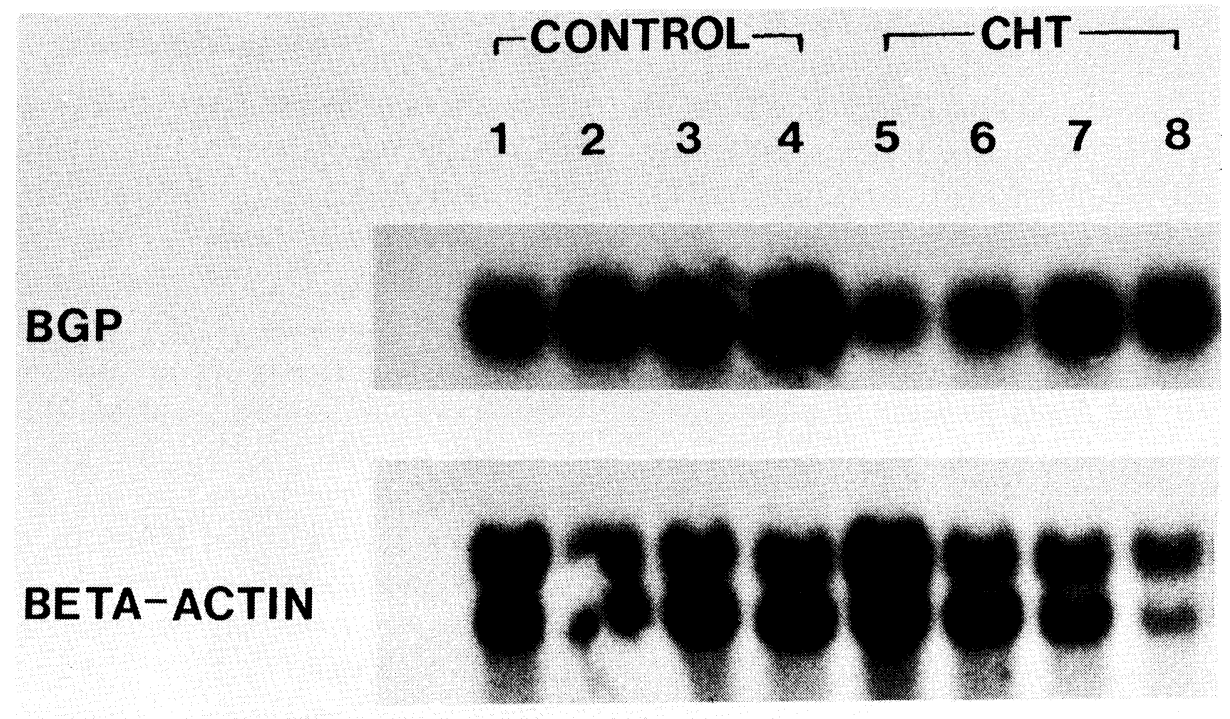

\section{$\begin{array}{llllllll}7 & 14 & 21 & 28 & 7 & 14 & 21 & 28\end{array}$}

\section{POSTNATAL AGE (DAYS)}

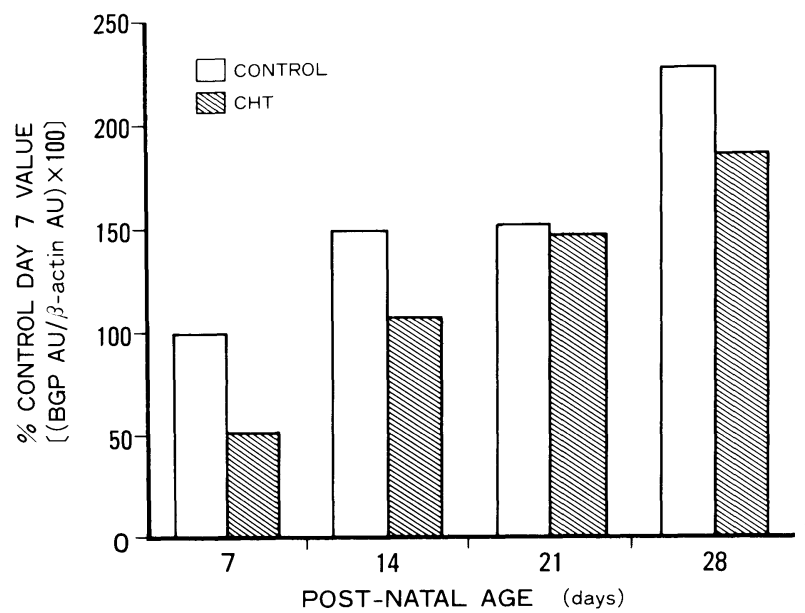

Fig. 7. Gene expression of mRNA for BGP in rat calvaria visualized by northern blot analysis (upper panel, a) and densitometric analysis of the autoradiographs (lower panel, b). a, Northern blot analysis of control (lanes 1-4) and hypothyroid (CHT; lanes 5-8) samples. Total cellular RNA (20 $\mu \mathrm{g} / \mathrm{lane})$ pooled from rat calvaria was hybridized with ${ }^{32} \mathrm{P}$-labeled probes for BGP and $\beta$-actin, individually. b, Densitometric analysis of the autoradiograph in a: relative absorbancy is expressed as a function of the percentage of the value on postnatal day 7 in the control. Control (open bars) and hypothyroid (CHT; hatched bars) samples are shown.

maternal behavior, there was no difference between the MMI-induced hypothyroid dams and the controls (data not shown). But it would be more reliable that the maternal thyroid function of the CHT pups could be kept euthyroid by simultaneous administration of both thyroxine' and
MMI subcutaneously [4, 10].

Finally, no age-associated increase in IGF-I gene expression was demonstrated in the CHT rat, and BGP gene expression in calvaria and serum intact molecular BGP levels were diminished in this model. All these facts were well correlated with the 
somatic growth retardation in the CHT rat during the first 4 weeks of life. But the mechanism of the strong IGF-I gene expression in the CHT rat is still unknown. We are currently investigating IGF-II and IGFBP-3 gene expressions in the CHT rat. Further studies are needed to clarify how hypothyroidism affects somatic growth and bone metabolism. It is particularly important to understand the autocrine/paracrine mechanisms of action of IGFs in the bone matrix, in vivo.

\section{Acknowledgements}

We are indebted to Dr. P. Rotwein and Dr. J. M. Wozney for the generous gifts of the probes for rat genomic IGF-I and rat BGP cDNA, respectively. The authors also wish to express their great appreciation to Dr. K. Hosoda (Institute for Biomedical Research, Teijin Ltd., Tokyo, Japan) for the measurement of serum intact molecular BGP levels in the rat, and to Dr. Y. Otoyama (Institute of Ciba Corning Diagnostics Co., Ltd., Funabashi, Chiba, Japan) for his useful advice on measuring serum IGF-I levels in the rat.

These studies were partially supported by Grants-in-Aid from the Ministry of Health and Welfare of Japan.

\section{References}

1. Burstein PJ, Draznin B, Johnson CJ, Schalch DS (1979) The effect of hypothyroidism on growth, serum growth hormone, the growth hormonedependent somatomedin, insulin-like growth factor, and its carrier protein in rats. Endocrinology 104: 1107-1111.

2. Glasscock GF, Nicoll CS (1981) Hormonal control of growth in the infant rat. Endocrinology 109: 176-184.

3. Blake HH, Henning SJ (1985) Effect of propylthiouracil dose on serum thyroxine, growth, and weaning in young rats. Am J Physiol 248: R524-530.

4. Näntö-Salonen K, Glasscock GF, Rosenfeld RG (1991) The effects of thyroid hormone on insulinlike growth factor (IGF) and IGF-binding protein (IGFBP) expression in the neonatal rat: prolonged high expression of IGFBP-2 in methimazoleinduced congenital hypothyroidism. Endocrinology 129: 2563-2570.

5. King RA, Smith RM, Meller DJ, Dahlenburg GW, Lineham JD (1988) Effect of growth hormone on growth and myelination in the neonatal hypothyroid rat. J Endocr 119: 117-125.

6. Marek J, Schüllerová M, Schreiberová O, Límanová $\mathrm{Z}$ (1981) Effect of thyroid function on serum somatomedin activity. Acta Endocrinol (Copenh) 96: 491-497.

7. Copeland KC, Franks RC (1984) Plasma somatomedin-C concentrations in congenital hypothyroidism. J Pediatr 104: 732-734.

8. Chernausek SD, Underwood LE, Utiger RD, Van Wyk JJ (1983) Growth hormone secretion and plasma somatomedin-C in primary hypothyroidism. Clin Endocrinol 19: 337-344.

9. Gallo G, de Marchis M, Voci A, Fugassa E (1991)
Expression of hepatic mRNAs for insulin-like growth factors-I and -II during the development of hypothyroid rats. J Endocr 131: 367-372.

10. Näntö-Salonen K, Rosenfeld RG (1992) Insulinlike growth factor binding protein expression in the hypothyroid rat is age dependent. Endocrinology 131: 1489-1496.

11. Glasscock GF, Gelber SE, Lamson G, McGeeTekula R, Rosenfeld RG (1990) Pituitary control of growth in the neonatal rat: effects of neonatal hypophysectomy on somatic and organ growth, serum insulin-like growth factors (IGF)-I and -II levels, and expression of IGF binding proteins. Endocrinology 127: 1792-1803.

12. Glasscock GF, Hein AN, Miller JA, Hintz RL, Rosenfeld RG (1992) Effects of continuous infusion of insulin-like growth factor I and II, alone and in combination with thyroxine or growth hormone, on the neonatal hypophysectomized rat. Endocrinology 130: 203-210.

13. Daughaday WH, Rotwein P (1989) Insulin-like growth factors I and II. Peptide, messenger ribonucleic acid and gene structures, serum, and tissue concentrations. Endocr Rev 10: 68-91.

14. Mohan S, Jennings JC, Linkhart TA, Baylink DJ (1988) Primary structure of human skeletal growth factor: homology with human insulin-like growth factor-II. Biochem Biophys Acta 966: 44-55.

15. Hauschka PV, Lian JB, Gallop PM (1975) Direct identification of the calcium-binding amino acid gamma-carboxyglutamate in mineralized tissue. Proc Natl Acad Sci USA 72: 3925-3929.

16. Delmas PD, Malaval L, Arlot ME, Meunier PJ (1985) Serum bone gla-protein compared to bone histomorphometry in endocrine diseases. Bone 6: 
339-341.

17. Martinez ME, Herranz L, de Pedro C, Pallardo LF (1986) Osteocalcin levels in patients with hyperand hypothyroidism. Horm Metabol Res 18: 212-214.

18. Johansen JS, Giwercman A, Hartwell D, Nielsen CT, Price PA, Christiansen C, Skakkebaek NE (1988) Serum bone gla-protein as a marker of bone growth in children and adolescents: correlation with age, height, serum insulin-like growth factor I, and serum testosterone. J Clin Endocrinol Metab 67: 273-278.

19. Zséli J, Bösze P, Lakatos P, Vargha P, Tarján G, Kollin E, Horváth C, László J, Holló I (1991) Serum bone GLA protein in streak gonad syndrome. Calcif Tissue Int 48: 387-391.

20. Delmas PD, Chatelain P, Malaval L, Bonne G (1986) Serum bone GLA-protein in growth hormone deficient children.J Bone Mineral Research 1: 333-338.

21. Markowitz ME, Dimartino-Nardi J, Gasparini F, Fishman K, Rosen JF, Saenger P (1989) Effects of growth hormone therapy on circadian osteocalcin rhythms in idiopathic short stature. J Clin Endocrinol Metab 69: 420-425.

22. Kanzaki S, Hosoda K, Moriwake T, Tanaka H, Kubo T, Inoue M, Higuchi J, Yamaji T, Seino Y (1992) Serum propeptide and intact molecular osteocalcin in normal children and children with growth hormone $(\mathrm{GH})$ deficiency: a potential marker of bone growth and response to $\mathrm{GH}$ therapy. J Clin Endocrinol Metab 75: 1104-1109.

23. Gardner MJ, Flint DJ (1990) Long-term reductions in $\mathrm{GH}$, insulin-like growth factor-I and body weight gain in rats treated neonatally with antibodies to rat GH. J Endocr 124: 381-386.

24. Engler H, Taurog A, Dorris ML (1982) Preferential inhibition of thyroxine and 3, 5, 3'triiodothyronine formation by propylthiouracil and methylmercaptoimidazole in thyroid peroxidase-catalyzed iodination of thyroglobulin. Endocrinology 110: 190-197.

25. Glasscock GF, Nicoll CS (1983) Hormonal control of growth in the infant rat: further evidence that neither thyrotropin nor thyroid hormones are transferred via milk to suckling pups. Endocrinology 112: 800-805.

26. Segawa M, Miyachi Y, Nagao N, Miyashita Y, Shoji $T$, Irie $M$ (1990) The evaluation of RIA for insulin-like growth factor-I (IGF-I). KAKUIGAKU 27: 1323-1329 (In Japanese).

27. Otoyama Y (Institute of Ciba Corning Diagnostics Co., Ltd., Funabashi, Chiba, Japan) Personal communication.

28. Hosoda K, Seino Y. Prepared for publication.

29. Hosoda K, Eguchi H, Nakamoto T, Kubota $T$, Honda H, Jindai S, Hasegawa R, Kiyoki M, Yamaji
T, Shiraki M (1992) Sandwich immunoassay for intact human osteocalcin. Clin Chem 38: 2233-2238.

30. Hosoda K, Kanzaki S, Eguchi H, Kiyoki M, Yamaji T, Koshihara Y, Shiraki M, Seino Y (1993) J Bone Mineral Research in press.

31. Chomczynski P, Sacchi N (1987) Single-step method of RNA isolation by acid guanidinium thiocyanate-phenol-chloroform extraction. Anal Biochem 162: 156-159.

32. Sambrook J, Fritsch EF, Maniatis T (1989) Analysis of RNA. In: Sambrook J, Fritsch EF, Maniatis T (eds) Molecular Cloning 2nd ed. Cold Spring Harbor Laboratory Press, Cold Spring Harbor, NY, vol 1: 7.37-7.57.

33. Rotwein P, Burgess SK, Milbrandt JD, Krause JE (1988) Differential expression of insulin-like growth factor genes in rat central nervous system. Proc Natl Acad Sci USA 85: 265-269.

34. Celeste AJ, Rosen V, Buecker JL, Kriz R, Wang EA, Wozney JM (1986) Isolation of the human gene for bone gla protein utilizing mouse and rat cDNA clones. EMBO J 5: 1885-1890.

35. Sambrook J, Fritsch EF, Maniatis T (1989) Synthesis of RNA probes by in vitro transcription of double-stranded DNA templates by bacteriophage DNA-dependent RNA polymerases. In: Sambrook J, Fritsch EF, Maniatis T (eds) Molecular Cloning 2nd ed. Cold Spring Harbor Laboratory Press, Cold Spring Harbor, NY, vol 2: 10.27-10.37.

36. Sambrook J, Fritsch EF, Maniatis T (1989) Nick translation of RNA. In: Sambrook J, Fritsch EF, Maniatis T (eds) Molecular Cloning 2nd ed. Cold Spring Harbor Laboratory Press, Cold Spring Harbor, NY, vol 2: 10.6-10.12.

37. Moats-Staats BM, Brady JL Jr, Underwood LE, D'Ercole AJ (1989) Dietary protein restriction in artificially reared neonatal rats causes a reduction of insulin-like growth factor-I gene expression. Endocrinology 125: 2368-2374.

38. Isgaard J, Möller C, Isaksson OGP, Nilsson A, Mathews LS, Norstedt G (1988) Regulation of insulin-like growth factor messenger ribonucleic acid in rat growth plate by growth hormone. Endocrinology 122: 1515-1520.

39. D'Ercole AJ, Stiles AD, Underwood LE (1984) Tissue concentrations of somatomedin C: further evidence for multiple sites of synthesis and paracrine or autocrine mechanisms of action. Proc Natl Acad Sci USA 81: 935-939.

40. Price PA (1983) Osteocalcin. In: Peck WA (ed) Bone and Mineral Research. Excerpta Med, Amsterdam, vol 1: 157-190.

41. Hauschka PV, Lian JB, Cole DEC, Gundberg CM (1989) Osteocalcin and matrix gla protein: vitamin K-dependent proteins in bone. Physiol Rev 69: 990-1047. 
42. Yamashita S, Morita S, Nagataki S (1990) Thyroid hormone. NIPPON RINSHO 48: 2797-2803 (In Japanese).

43. Samuels HH, Forman BM, Horowitz ZD, Ye ZS (1989) Regulation of gene expression by thyroid hormone. Annu Rev Physiol 51: 623-639.

44. Mackowiak S, Gerstenfeld LC (1988) Effect of thyroid hormone on osteocalcin synthesis. $J$ Bone Min Res 3: S172.

45. Price PA, Nishimoto SK (1980) Radioimmunoassay for the vitamin K-dependent protein of bone and its discovery in plasma. Proc Natl Acad Sci USA 77: 2234-2238.

46. Price PA, Parthemore JG, Deftos LJ (1980) New biochemical marker for bone metabolism: measurement by radioimmunoassay of bone Gla protein in the plasma of normal subjects and patients with bone disease. J Clin Invest 71: 1316-1321.
47. Brown JP, Delmas PD, Malaval L, Edouard C, Chapuy MC, Meunier PJ (1984) Serum bone Gla-protein: a specific marker for bone formation in postmenopausal osteoporosis. Lancet 1: 1091-1093.

48. Gundberg CM, Weinstein RS (1986) Multiple immunoreactive forms of osteocalcin in uremic serum. J Clin Invest 77: 1762-1767.

49. Taylor AK, Linkhart S, Mohan S, Christenson RA, Singer FR, Baylink DJ (1990) Multiple osteocalcin fragments in human urine and serum as detected by a midmolecule osteocalcin radioimmunoassay. $J$ Clin Endocrinol Metab 70: 467-472.

50. Kurihara N, Hosoda K, Kiyoki M, Yamaji T, Koshihara Y, Ikeda K, Kumegawa M, Shiraki M (1991) Novel sandwich enzyme immunoassay systems for intact and N-terminal human osteocalcin. J Bone Mineral Res 6: S157. 